\title{
Alle kan gjøre noe \\ - Veiledende materiell til kommunene for forebygging av selvskading og selvmord
}

\author{
Av Anita I. Tormoen og Ingeborg Lunde
}

\begin{abstract}
Intervensjoner på flere nivåer er nødvendig for å forebygge og behandle selvmordsatferd og selvskading. Kommunene med sitt ansvar for å ivareta egne innbyggere og sikre tilgang på nødvendige helsetjenester er en viktig arena for forebyggende tiltak.
\end{abstract}

ANSATTE OG FRIVILLIGE i kommunene må tenke bredt og favne vidt. En kommuneplan for forebygging av selvmord og selvskading bør inneholde tiltak som retter seg mot hele befolkningen, men også selektive tiltak rettet mot sårbare grupper og indikative tiltak rettet mot enkeltpersoner som selvskader og/eller har selvmordsatferd.

Studier viser at mange har vært i kontakt med helsetjenesten i tiden før et selvmord, og ulike helsetjenester i kommunene er derfor en viktig arena for tidlig avdekking av selvskading og selvmordsatferd. I tråd med samhandlingsreformen skal kommunene ta stadig større ansvar for forebygging, oppfølging og behandling av psykiske lidelser, herunder håndtering av selvskading og selvmordsatferd. Spesialisthelsetienesten har lenge hatt nasjonale retningslinjer for forebygging av selvmord å forholde seg til, mens kommunehelsetjenesten ikke har hatt noen tilsvarende føringer.

Helsedirektoratet (HDIR) bestemte i Handlingsplan for forebygging av selvmord og selvskading 2014-2017 at det skulle utarbeides et veiledende materiell for kommunene om forebygging av selvskading og selvmord. Materiellet skulle omtale kommunenes mulighet for å

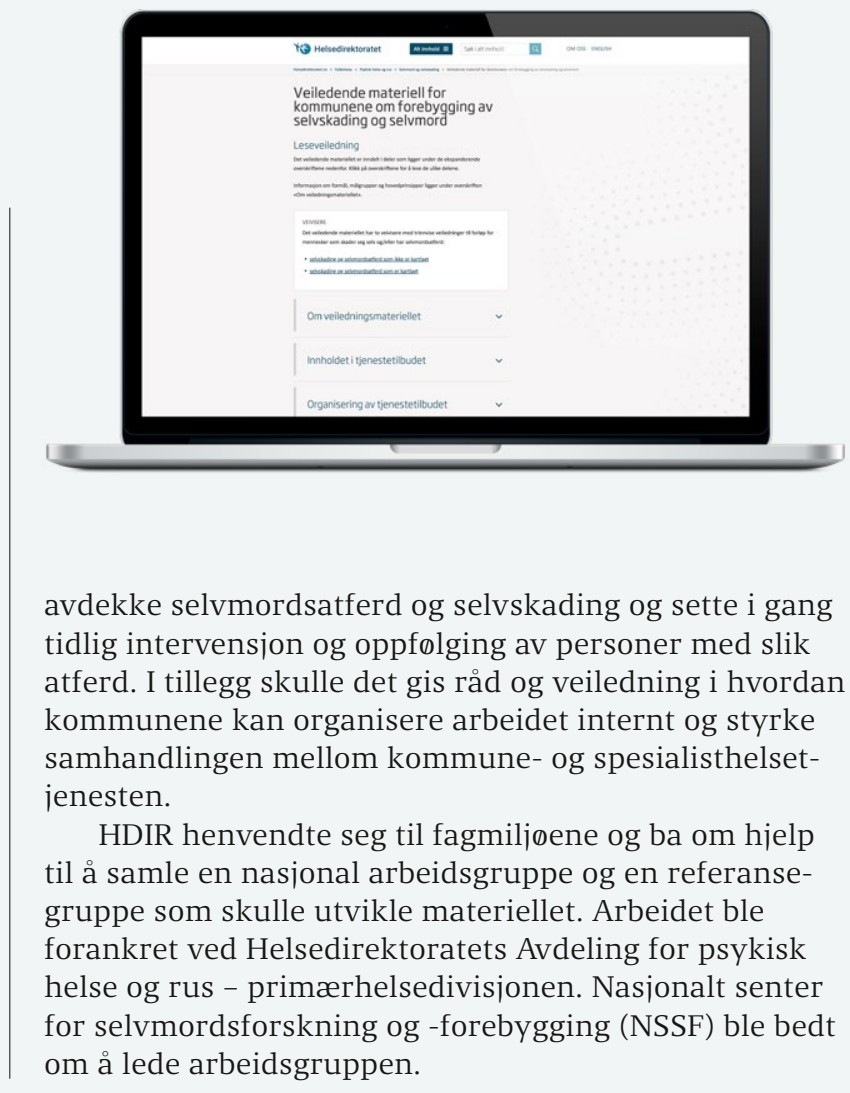


Arbeidsgruppen ble konstituert i et første møte i mars 2015, og besto i tillegg til NSSF av representanter fra de aktører HDIR onsket at skulle delta; to fra de regionale ressurssentrene om vold, traumatisk stress og selvmordsforebygging (RVTS-ene), én fra Nasjonalt kompetansesenter for psykisk helsearbeid (NAPHA), én fra spesialisthelsetjenesten og én fra kommunehelsetienesten. De ulike deltagernes kompetanse og arbeidsområde utfylte hverandre og skulle tjene formålet om å lage et veiledende materiell som kunne omhandle flere arenaer i kommunene, men også dekke overgangen fra spesialisthelsetjeneste til tjenester i kommunene.

Leder av arbeidsgruppen inviterte relevante brukerog pårørendeorganisasjoner til å sitte i en referansegruppe. Denne referansegruppen besto av Mental Helse Ungdom, Landsforeningen for etterlatte etter selvmord (LEVE), Landsforeningen for forebygging av selvskading og selvmord (LFSS) og Landsforeningen mot stoffmisbruk (LMS). Referansegruppen deltok på tre utvalgte dialogmøter, og fikk tilsendt arbeidsgruppens første utkast til materiell. Arbeidsgruppen møttes seks ganger etter oppstart, og siste samling ble avholdt i november 2015. Derimellom jobbet deltagerne enkeltvis eller i samarbeid med sine definerte områder.

\section{Resultater}

Arbeidsgruppen prioriterte å løse oppdraget med å utvikle det veiledende materiellet ved å jobbe frem utkast innen fire hovedområder:
1. To veivisere som beskriver hvordan skolehelsetienesten og fastlegene kan fange opp og henvise personer med selvskading og selvmordsforsøk til spesialisthelsetjenesten, eller følge opp de som allerede er i behandling eller er skrevet ut.

2. Oppsummering av kunnskap om sosial overføring av selvskading og selvmordsforsøk, og smitteeffekt etter selvmord. Informasjon om dette kan bidra til å motvirke epidemier av selvskading og selvmordsforsøk på ulike arenaer i kommunene.

3. To faktaark; ett om selvskading og ett om selvmordsforsøk.

4. Litteratursøk, og en første giennomgang av eksisterende tiltak vedrørende skoleprogrammer som omtaler forebygging av psykiske lidelser, selvmordsforsøk og selvskading. Formålet var å kunne gi holdepunkter for hva som synes å fungere for skoler som skal forebygge selvmord og selvskading. Dette arbeidet ble påbegynt, men ikke sluttført.

\section{Materiellet - første rene utgivelse for nett fra HDIR}

Arbeidsgruppen leverte sine skriftlige utkast til HDIR. Utvikling av maler for elektronisk publisering var i prosess internt i HDIR da utkastene ble levert, og arbeidsgruppen skulle samarbeide om å tilpasse teksten når HDIR hadde fått avklart muligheter og begrensninger for sine plattformer på nett.

Tilbakemeldingen var at arbeidsgruppen hadde levert et godt og grundig arbeid som HDIR skulle til-

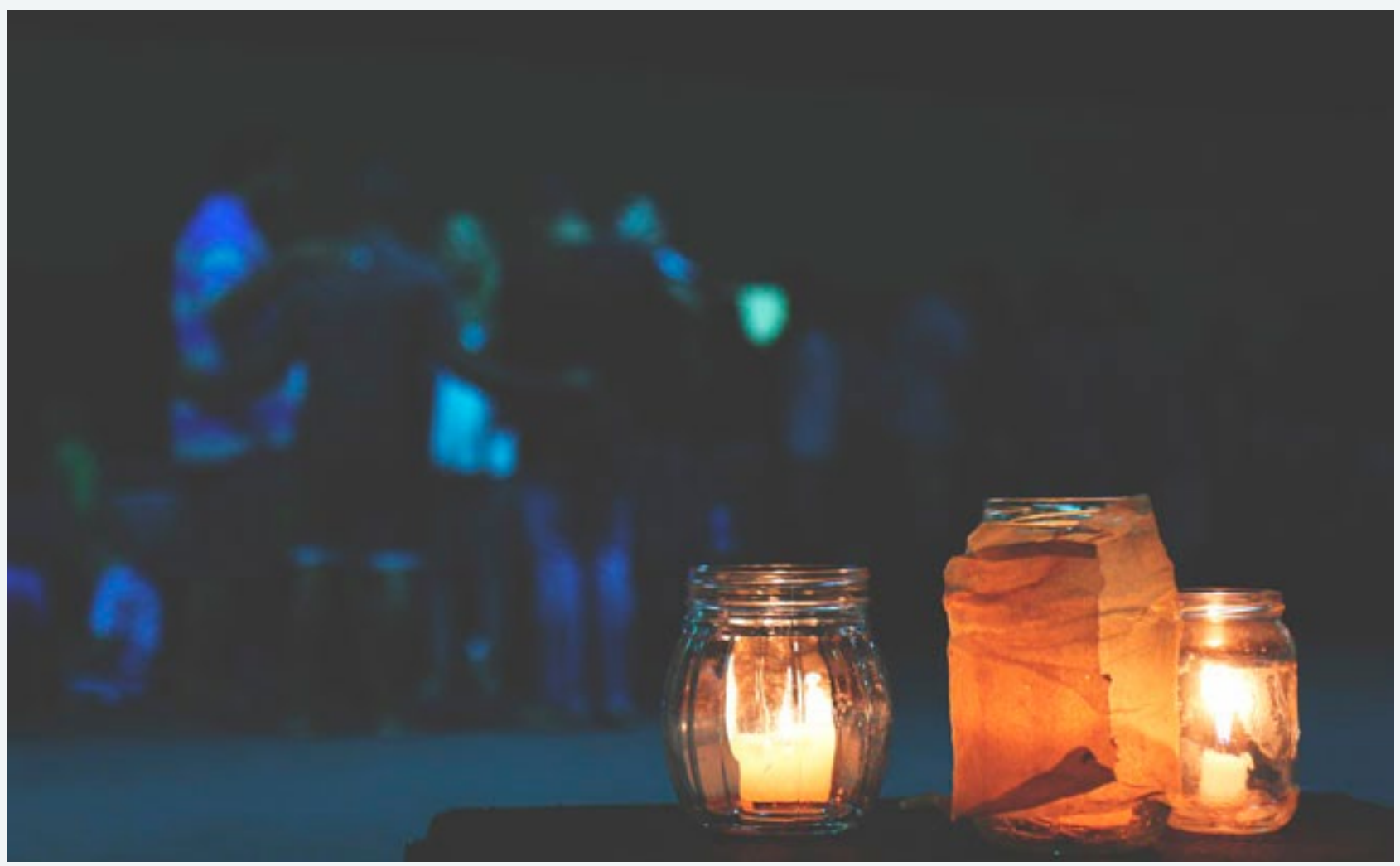


passe sine maler. En revisjon førte til at vi inkluderte mer om hvordan kommunene kan organisere arbeidet med selvskading og selvmord internt, og hvordan samhandlingen mellom kommune- og spesialisthelsetjeneste kan styrkes.

NSSF, RVTS Øst og HDIR forenklet og tilpasset all tekst til et elektronisk format. Dokumentet ble supplert med tekst vedrørende lovverk, og omgiort med tanke på de elektroniske rammene for materiellet. I tillegg ble øvrig tekst giennomgått og supplert ut fra tilbakemeldinger fra avdelinger i HDIR for å samstemme med øvrige normerende produkter som HDIR utgir.

Materiellet ble lagt ut på HDIRs nettsider for en høringsrunde. HDIR inviterte 114 instanser og mottok 25 høringsuttalelser fra relevante instanser. Disse uttalelsene ble forelagt arbeidsgruppen, og alle ble grundig vurdert. Flere av uttalelsene medførte endringer i materiellet. HDIR ferdigstilte materiellet i 2017, og det ble lansert av helseministeren i juli samme år.

\section{Materiellets struktur}

Det endelige materiellet består av kapitler

med følgende innhold:

- To veivisere for forløp ved selvskading/ selvmordsatferd

- Bakgrunnsstoff

- Innhold i tienestetilbudet

- Organisering av tienestetilbudet

- Forebygging av selvmord og selvskading på ulike arenaer

- Fakta om selvskading, selvmordsforsøk og sosial overførbarhet/smitte

- Litteraturliste

Alle temaområdene er samlet i såkalte ekspanderende overskrifter der en under hvert kapittel finner ett eller flere underkapitler med konkret informasjon, og råd om tiltak.

\section{Første tilbakemeldinger og plan for videre implementering}

RVTS-ene er giennom sitt tilskuddsbrev gitt ansvar for å bistå kommunene med implementering av materiellet. Representanter fra de fem RVTS-ene hadde i desember 2017 møte i Kristiansand hvor man diskuterte og inspirerte hverandre med tanke på hvordan implementeringen kan foregå. De fem RVTS-ene er noe ulikt organisert, og har ansvar for ulike regioner. Dette vil medføre at RVTS-ene velger ulike strategier for å spre informasjon om materiellet, og hielpe kommunene å ta det i bruk. RVTS-ene møttes på nytt i juni i år for å dele sine første erfaringer med implementeringsarbeidet. Alle RVTS-er er i gang med implementeringsarbeidet, responderer på bestillinger fra kommunene og bidrar med ulike aktiviteter. RVTS har startet med å informere om materiellet i alle sammenhenger der man driver kompetanseheving av kommunalt ansatte. Informasion

om materiellet deles på Facebook, nettsider og i nyhetsbrev. Flere RVTS-er utarbeider enkle foldere eller brosiyrer der man giør det mest sentrale innholdet lett tilgiengelig, og informerer om hvordan man går fram for å finne materiellet på nett.

RVTS sin erfaring så langt er at få på egenhånd har oppdaget og giort seg kjent med materiellet. Det er behov for at RVTS aktivt går ut og opplyser om det. RVTS Vest har valgt å sende mail til alle kommuner i sin region, med tilbud om å bistå med implementeringsarbeid dersom kommunen onsker det. Alle RVTS-er baker kunnskap om materiellet inn i sine pågående kompetansehevingsprogrammer. På RVTS Øst sine kommunale kompetansehevingsprogrammer er det 100-200 deltakere jevnt over, og det er mange tema det skal undervises i. Det blir derfor få muligheter til å gå detaljert giennom innholdet i materiellet. RVTSØst velger derfor i tillegg å holde fordypningsdager om avdekking, oppfølging og behandling av selvskading og selvmordsatferd for deltakerne på disse programmene. Flere andre RVTS-er vurderer å giøre det samme. RVTS Ost har allerede giennomfort to fulle fordypningsdager i arbeid med selvskading og selvmordsatferd giennom programmet «Traume og selvmordsforebyggende kompetanse bydel», rettet

RVTS-ene trenger å giore seg erfaringer med hvilke metoder for implementering som fungerer best, og kommunisere mer med hverandre rundt hva som kan være kloke strategier $i$ dette arbeidet.

mot bydeler i Oslo. På disse fordypningsdagene gis det plass til maks 40 personer for i større grad å kunne gi rom for felles refleksion og praktisk øvelse. Vi har for eksempel fått tid til å gå skikkelig giennom materiellets veiviser for kartleggende og oppfølgende samtaler med enkeltpersoner med selvskading og selvmordsatferd. Ansatte fra ulike kommunale settinger som skolehelsetjeneste, psykisk helsetjeneste, bydelspsykologer, NAV og barneverntjeneste har deltatt, og de ansatte har fått mulighet til å diskutere samarbeid og samhandling seg imellom. Begge disse dagene er blitt svært godt evaluert, og det er RVTS Øst sitt inntrykk at mer kunnskap om hvordan man skal håndtere selvskadende og suicidale personer er etterlengtet hos de ansatte i kommunene.

RVTS Sør, Midt og Vest har kontaktet Fylkesmennene for å drøfte implementeringsstrategi i sin region. RVTS Sør velger i høst å avholde flere åpne fylkessamlinger om materiellet i sin region, med assistanse fra RVTS Øst. RVTS Øst har en plan om å tilby ytterligere implementeringsstøtte til én eller flere utvalgte kommuner, og er allerede i dialog med en av bydelene 
i Oslo rundt dette. Implementeringsplan er ikke klar ennå, men skal utvikles i samarbeid med sentrale kontaktpersoner og ledere av tienestene i denne bydelen. Alle RVTS-ene bidrar med å arrangere VIVATs kurs Forstehielp ved selvmordsfare for ansatte i kommuner.

Implementeringsarbeidet er altså godt i gang. Våren 2018 arrangerte HDIR møte med representanter fra alle RVTS samt NSSF, slik at RVTS-ene kunne dele sine første planer og erfaringer med å spre kunnskap fra materiellet. Man drøftet på dette møtet hva som kan være de mest effektive metodene for implementering. RVTS-ene trenger å giøre seg erfaringer med hvilke metoder for implementering som fungerer best, og kommunisere mer med hverandre rundt hva som kan være kloke strategier i dette arbeidet. Det er mange kommuner i Norge, og det skal bli spennende å se hvordan man mest effektivt kan nå frem med kunnskap fra materiellet til hver enkelt ansatt i kommunene. NSSF påpekte behovet for å evaluere implementeringen.

\begin{abstract}
Veien videre
Det vurderes å giøre materiellet ytterligere kjent også giennom deltagelse i en folkeopplysningskampanje om selvmord og selvmordsatferd. Dette arbeides det nå med i den nasjonale gruppen som Helsedirektoratet leder. Erfaringer så langt tyder på at materiellet bør giøres mer kjent for kommunene. De som har deltatt på kurs eller har lest giennom materiellet gir tilbakemelding på at innholdet er meget relevant og etterlengtet. Kursene til RVTS får gode evalueringer.

NSSF planlegger sammen med RVTS-ene å evaluere implementeringen etter en stund - blant annet giennom bruk av registerdata som allerede samles inn i kommunene, for å se om materiellet har ført til noen endringer i kommunenes praksis.
\end{abstract}

Anita J. Tørmoen er førsteamanuensis, PhD, ved NSSF. Ingeborg Lunde er spesialrådgiver og psykologspesialist ved RVTS øst. Begge har vært sentrale i arbeidsgruppen som utviklet materiellet.

\section{Utdanning i DBT}

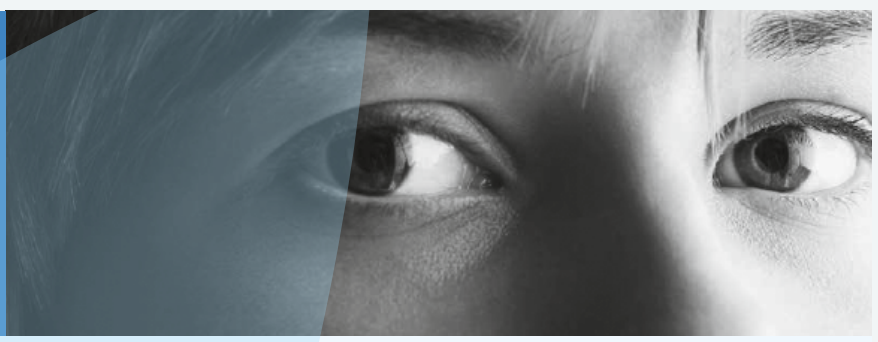

Dialektisk atferdsterapi (DBT) er anbefalt som behandlingsmetodikk overfor pasienter med selvskading, selvmordsforsøk og ustabil personlighetsforstyrrelse.

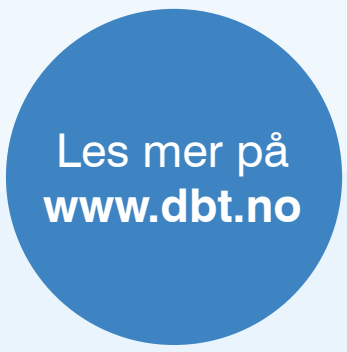

Nasjonalt senter for selvmordsforskning og -forebygging tilbyr et komplett utdanningsforløp på norsk 